Vol. 6(1997): 313-322.

\title{
Effect of fertilization on soil phosphorus in a long-term field experiment in southern Finland
}

\author{
Antti Jaakkola, Helinä Hartikainen and Riitta Lemola \\ Department of Applied Chemistry and Microbiology, PO Box 27, FIN-00014 University of Helsinki, Finland, \\ e-mail:antti.jaakkola@helsinki.fi
}

\begin{abstract}
A field experiment was established in 1978 on a loam soil ( $\mathrm{pH}$ in $\mathrm{CaCl}_{2} 7.1$ ) to monitor gradual changes in the soil $\mathrm{P}$ status as response to different $\mathrm{P}$ fertilization regimes. For 18 years, cereals or grass were cultivated without $\mathrm{P}$ fertilization $\left(\mathrm{P}_{0}\right)$ or with annual $\mathrm{P}$ application of $35 \mathrm{~kg} \mathrm{ha}^{-1}\left(\mathrm{P}_{1}\right)$ or 70 $79 \mathrm{~kg} \mathrm{Pha}^{-1}$ and $71-83 \mathrm{~kg} \mathrm{~K} \mathrm{ha}^{-1}\left(\mathrm{P}_{2} \mathrm{~K}\right)$. The effects of the treatments on the crop yield varied yearly. The Chang and Jackson fractionation analysis revealed that fertilizer P not taken up by the plant crops was mostly in the $\mathrm{NH}_{4} \mathrm{~F}$ extract and to a lesser extent in the $\mathrm{NaOH}$ extract. The $\mathrm{NH}_{4} \mathrm{~F}$-extractable $\mathrm{P}$ proved also to be the main $\mathrm{P}$ source for plants. However, the changes in the reserves of inorganic and organic $\mathrm{P}$ did not agree very well with the calculated $\mathrm{P}$ balance in soil (applied $\mathrm{P}$ minus plant $\mathrm{P}$ uptake). This disproportion was partly explained by the soil movement from plots to the neighbouring ones during the experiment. Phosphorus extractable in acid ammonium acetate or water decreased gradually when no $\mathrm{P}$ was applied and increased with increasing $\mathrm{P}$ accumulation. The changes in the inorganic $\mathrm{P}$ reserves due to different $\mathrm{P}$ fertilization history were reflected a little more sensitively in the water extraction test than in the acid acetate test.
\end{abstract}

Key words: acid ammonium acetate extraction, inorganic $\mathrm{P}$ fractions, $\mathrm{P}$ accumulation, $\mathrm{P}$ balance, $\mathrm{P}$ depletion, water extraction

\section{Introduction}

Effective sorption of phosphorus by hydrated oxides of iron and aluminium is typical of Finnish mineral soils (Kaila 1963, Hartikainen 1979). This efficient retention restricts losses with seepage water, but also decreases the availability of phosphorus to plants. This is why more phosphorus has been applied to soils over the years than has been removed with the plant crops. This has resulted in accumulation of phosphorus in the cultivated soils, the excess has been calculated to average $800 \mathrm{~kg} \mathrm{ha}^{-1}$ since 1920 (I. Saarela, personal communication). The most marked accumulation has taken place during the last three decades.

The enrichment of phosphorus in the surface soils may increase the load of phosphorus dissolved in the surface runoff water and bound in 


\section{Jaakkola, A. et al. Effect of fertilization on soil phosphorus}

eroded soil material and, thus, contribute to eutrofication (Yli-Halla et al. 1995). On the other hand, accumulation gradually leads to saturation of the sorption sites and decreases their retention strength (Barrow 1974, Hartikainen 1991), which improves the efficiency of fertilizer phosphorus added to crops. Long-term residual contributions of phosphorus fertilizer to crop yields and phosphorus uptake has been shown in numerous studies (e.g. Campbell 1965, Halvorsson and Black 1985). In terms of crop production, accumulation is therefore beneficial until an economical optimum is reached.

In this study changes of various soil phosphorus fractions as a function of different fertilization history and withdrawal by plant crops were investigated in a long-term field experiment. The sensitivity of two phosphorus tests to describe these changes was compared to evaluate their use as a basis for fertilization recommendations.

\section{Material and methods}

The field experiment was established on a farm in southern Finland $\left(60^{\circ} 47^{\prime} \mathrm{N}, 24^{\circ} 55^{\prime} \mathrm{E}, 110\right.$ $\mathrm{m}$ asl) in 1978 and it is still continuing. The field slopes to the south east c. $6 \%$. The particle size distribution determined according to Elonen (1971) was: fraction $>200 \mu \mathrm{m} 8 \%, 60-200 \mu \mathrm{m}$ $23 \%, 20-60 \mu \mathrm{m} 22 \%, 2-20 \mu \mathrm{m} \mathrm{35 \%}$ and $<2 \mu \mathrm{m}$ $12 \%$ (a loam soil). The concentration of organic carbon determined by a modified wet digestion method (Graham 1948) was $2.8 \%$, and $\mathrm{pH}$ in 0.01 $\mathrm{M} \mathrm{CaCl}_{2}$ was 7.1. The dry bulk density of the soil samples ground to pass a 2-mm sieve was $1.14 \mathrm{~kg} \mathrm{l}^{-1}$. Amorphous $\mathrm{Fe}$ and $\mathrm{Al}$ oxides extracted by an acid ammonium oxalate solution (Tamm 1922, modified by Niskanen 1989) were measured by atomic absorption spectrophotometry (AAS). Their concentrations were: $16 \mathrm{mmol} \mathrm{kg}^{-1}$ $\mathrm{Fe}_{\text {ox }}$ and $76 \mathrm{mmol} \mathrm{kg}^{-1} \mathrm{Al}_{\text {ox }}$. The soil had been cultivated conventionally for decades before the experiment started.
The design of the experiment consists of two factors with two levels each: without and with PK fertilizer as well as without and with an extra superphosphate application. The treatments $\mathrm{P}_{0}, \mathrm{P}_{1}, \mathrm{P}_{1} \mathrm{~K}$ and $\mathrm{P}_{2} \mathrm{~K}$ are replicated 6, 9, 4 and 6 times, respectively. They were arranged in plots of 20 by $15 \mathrm{~m}\left(\mathrm{P}_{0}\right.$ and $\left.\mathrm{P}_{1} \mathrm{~K}\right)$ or 5 by $15 \mathrm{~m}\left(\mathrm{P}_{1}\right.$ and $\left.\mathrm{P}_{2} \mathrm{~K}\right)$. Nitrogen has been applied at $100 \mathrm{~kg} \mathrm{ha}^{-1}$ yearly. The fertilizers were placed at depths of $6-8 \mathrm{~cm}$ as calcium ammonium nitrate $\left(\mathrm{NH}_{4}: \mathrm{NO}_{3}\right.$ $=1: 1)$ or NPK compound fertilizer $\left(\mathrm{NH}_{4}: \mathrm{NO}_{3}\right.$ $\approx 2: 1$ ). The treatments were as follows:

$\begin{array}{cccc}\text { Treatment } & \mathrm{N} \mathrm{kg} \mathrm{ha}^{-1} & \mathrm{P} \mathrm{kg} \mathrm{ha}^{-1} & \mathrm{~K} \mathrm{~kg} \mathrm{ha}^{-1} \\ \mathrm{P}_{0} & 100 & 0 & 0 \\ \mathrm{P}_{1} & 100 & 35 & 0 \\ \mathrm{P}_{1} \mathrm{~K} & 100 & 44\left(35^{*}\right) & 83\left(71^{*}\right) \\ \mathrm{P}_{2} \mathrm{~K} & 100 & 79\left(70^{*}\right) & 83\left(71^{*}\right) \\ \text { * in 1992-1995 } & & & \end{array}$

Treatments $\mathrm{P}_{0}, \mathrm{P}_{1}$ and $\mathrm{P}_{2} \mathrm{~K}$ are discussed in this paper. Four replicates situated in separate blocks were chosen for each treatment. The cereal crops were harvested with a combine harvester. The straw was ploughed into the soil in 1978 and 1979. Thereafter it was removed yearly with a pick-up baler. Both grain and straw yields of cereals were weighed from a net plot of 4 by $11 \mathrm{~m}$ except for the years 1978 and 1979 when the straw was not weighed. Grass yields $(1988,1992)$ were harvested once in each season and weighed from a net plot of 1.5 by $10 \mathrm{~m}$. Plant samples representing the net plots were taken for the determination of dry matter yield and analyzed for phosphorus from ashed samples with the ammonium vanadate-molybdate method.

Soil samples representing the plough layer ( $23 \mathrm{~cm}$ deep) of the net plots were taken yearly after the harvest and air dried. The samples from the years 1978, 1984, 1990 and 1995 were studied more closely for this paper. The inorganic phosphorus reserves bound by various soil components were investigated by the fractionation method of Chang and Jackson (as modified by Hartikainen 1979). Organic phosphorus was de- 
Vol. 6 (1997): 313-322.

termined as a difference between $\mathrm{H}_{2} \mathrm{SO}_{4}$ extractable $\mathrm{P}(0.1 \mathrm{M}$, extraction ratio of $1: 100)$ in the ignited $\left(1 \mathrm{~h}\right.$ at $\left.550^{\circ} \mathrm{C}\right)$ and untreated sample. The plant available reserves were estimated by an acid ammonium acetate test used routinely in Finland (Vuorinen and Mäkitie 1955) and by the van der Paauw and Sissingh water extraction test modified by Hartikainen (1979).

\section{Results}

\section{Yields and $P$ balance}

The yearly variation of grain yields was remarkable (Fig. 1). Without $\mathrm{P}$ fertilization the yields were lower, but the relative decrease varied during the experiment. As compared to the $\mathrm{P}_{0}$ treatment, the increase in the average grain yield in the $\mathrm{P}_{1}$ treatment remained statistically insignificant (Table 1). The $\mathrm{P}_{2} \mathrm{~K}$ treatment on the contrary, increased the yield significantly. This positive response was at least partly due to $\mathrm{K}$ fertilization, because the treatment $\mathrm{P}_{1} \mathrm{~K}$ did not differ from $\mathrm{P}_{2} \mathrm{~K}$.

The straw and grass yields also varied considerably annually (Fig. 2). Significant differences due to the treatments were found in five years but the differences appeared to be similar in most years. However, the average straw or grass yield was not increased statistically significantly by $\mathrm{P}$ and $\mathrm{K}$ applications (Table 1).

The concentration of phosphorus in grain varied annually between 2.8 and $5.3 \mathrm{~g} \mathrm{~kg}^{-1}$
(Fig. 3). However, all treatments had the same average concentration of $4.0 \mathrm{~g} \mathrm{~kg}^{-1}$. The phosphorus concentration in straw varied between 0.5 and $4.0 \mathrm{~g} \mathrm{~kg}^{-1}$ (Fig. 4), being $2.2 \mathrm{~g} \mathrm{~kg}^{-1}$ on average. It was not affected by the fertilization.

When calculating the P uptake (Fig. 5) the unweighed straw yields in 1978 and 1979 were expected to be equal to the grain yields. During the eighteen years of experiment the average yearly uptake of phosphorus was 12.0, 14.2 and $16.9 \mathrm{~kg} \mathrm{ha}^{-1}$ in the treatments $\mathrm{P}_{0}, \mathrm{P}_{1}$ and $\mathrm{P}_{2} \mathrm{~K}$, respectively. The variation in the treatments and individual years was between 3.1 and $23.6 \mathrm{~kg}$ ha $^{-1}$.

The P balance in soil was calculated as the difference between the phosphorus application and the removal with the yields. Cumulative $\mathrm{P}$ balance from the very beginning of the experiment is given in Fig. 6. In treatment $P_{0}$ it was negative while in the other treatments it was positive increasing rather linearly in the course of the experiment. During eighteen years the removal of P from the plot cultivated without phosphorus fertilization amounted to $206 \mathrm{~kg} \mathrm{ha}^{-1}$ while the $P_{1}$ and $P_{2} K$ treatments resulted in a phosphorus accumulation of 384 and $1037 \mathrm{~kg} \mathrm{ha}^{-1}$, respectively.

\section{Soil $P$ fractions}

The soil $\mathrm{pH}$ was not significantly altered during the experiment (Table 2). To study the response of soil $\mathrm{P}$ to different fertilization regimes in more detail, the changes in the various inorganic $P$ fractions were investigated. The $\mathrm{P}$ fertilization

Table 1. Average yield 1978-1995 $\left(\mathrm{kg} \mathrm{ha}^{-1} \mathrm{DM}\right)$ in the various fertilization treatments. ${ }^{1}$

\begin{tabular}{lcccc}
\hline & & & Treatment & \\
& $\mathrm{P}_{0}$ & $\mathrm{P}_{1}$ & $\left(\mathrm{P}_{1} \mathrm{~K}\right)$ & $\mathrm{P}_{2} \mathrm{~K}$ \\
\hline Grain yield & $2198^{\mathrm{a}}$ & $2563^{\mathrm{ab}}$ & $2839^{\mathrm{b}}$ & $3057^{\mathrm{b}}$ \\
Straw yield & $2028^{\mathrm{a}}$ & $2466^{\mathrm{a}}$ & $2836^{\mathrm{a}}$ & $3115^{\mathrm{a}}$ \\
\hline
\end{tabular}

Means in each row followed by a common letter do not differ significantly (Tukey, $\mathrm{P}=0.05$ ).

* Grass yield 1988 and 1992. 


\section{AGRICULTURAL AND FOOD SCIENCE IN FINLAND}

Jaakkola, A. et al. Effect of fertilization on soil phosphorus

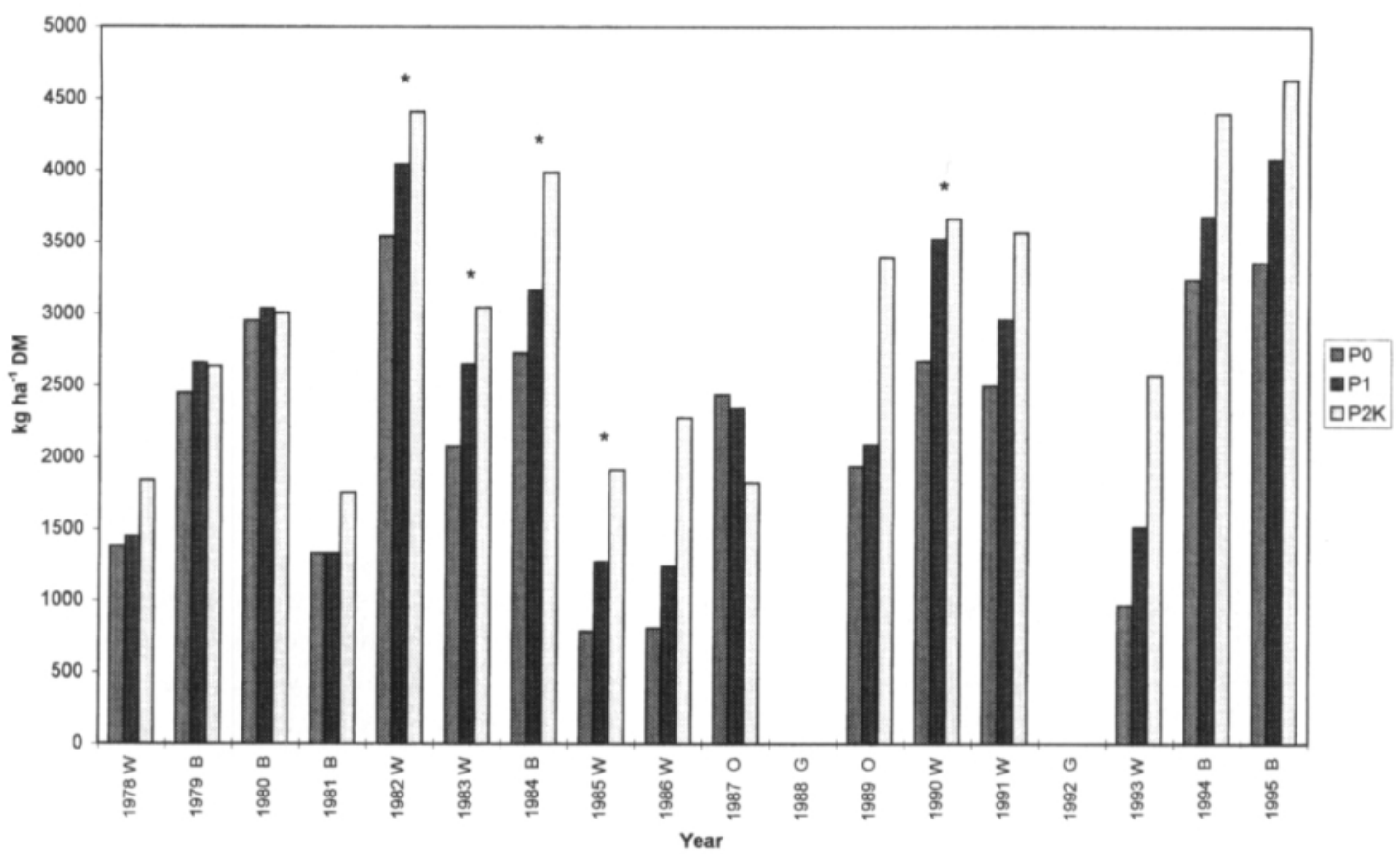

Fig. 1. Grain yield. Letter after year denotes the following crops: $\mathrm{B}=$ barley, $\mathrm{W}=$ spring wheat, $\mathrm{O}=$ oats, $\mathrm{G}=$ rye grass. *significant difference between treatments $(\mathrm{P}=0.05)$.

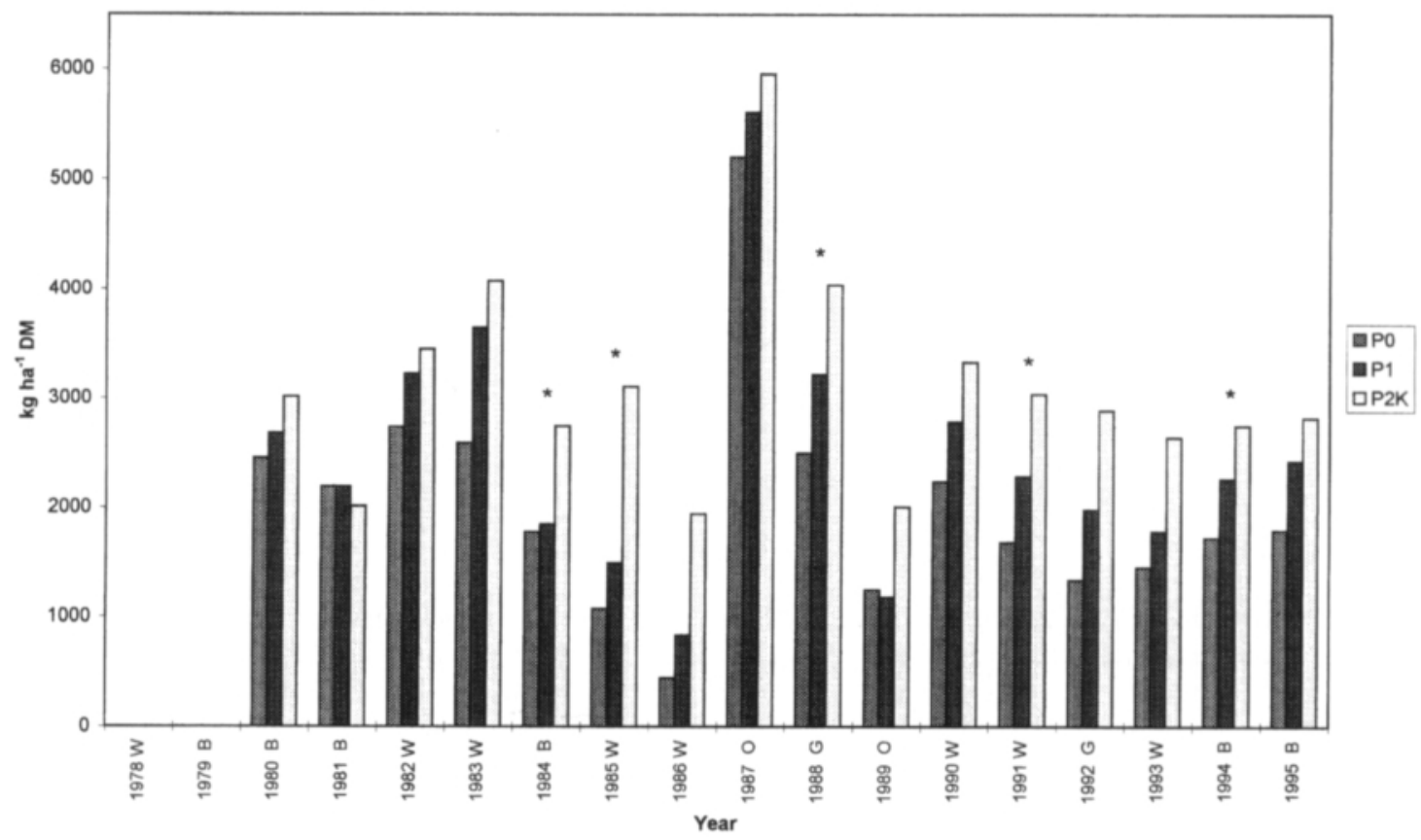

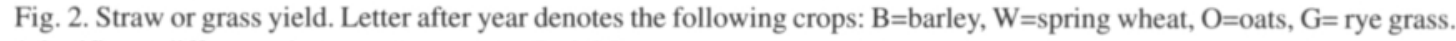
*significant difference between treatments $(\mathrm{P}=0.05)$. 


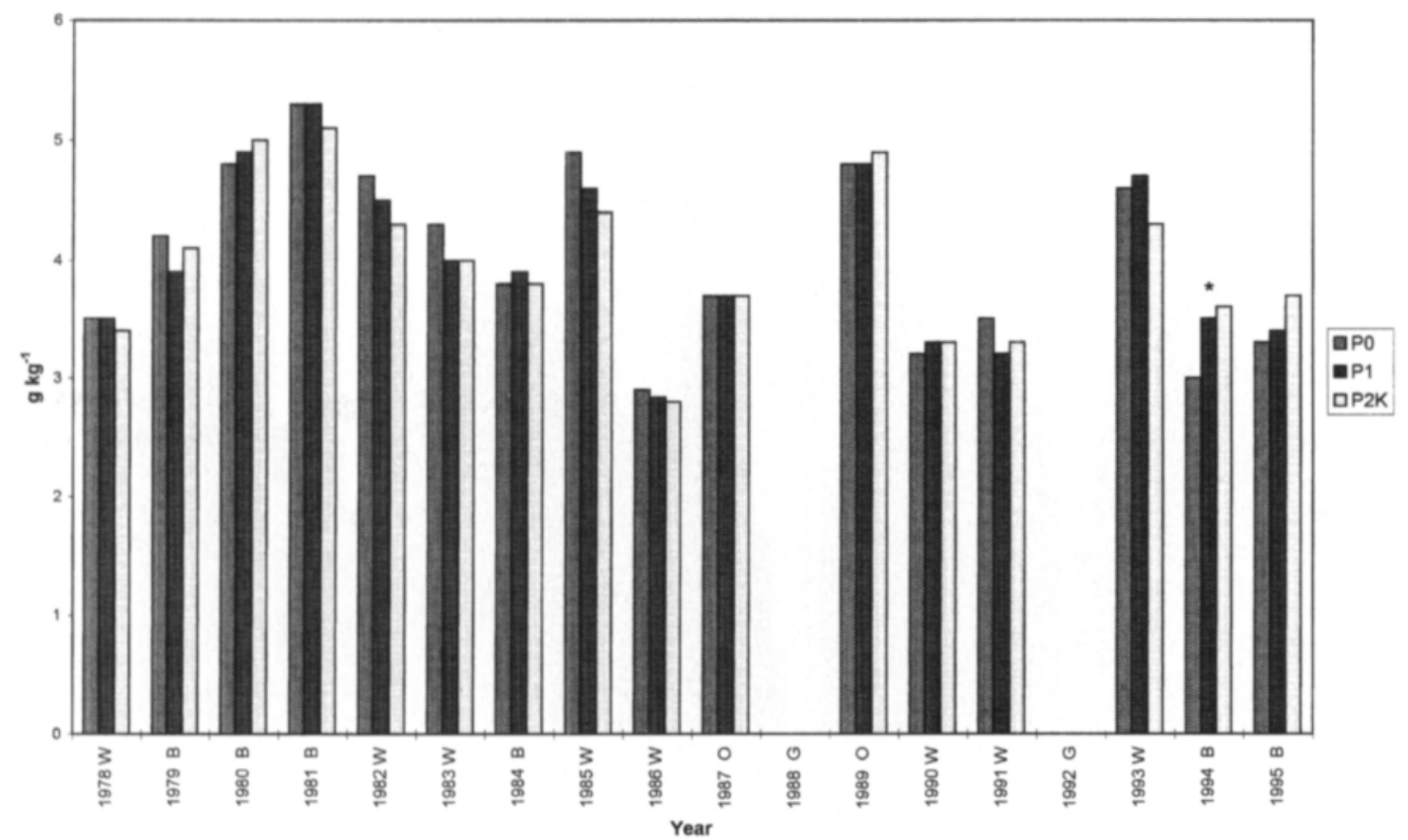

Fig. 3. $\mathrm{P}$ concentration in grain (DM). Letter after year denotes the following crops: $\mathrm{B}=$ barley, $\mathrm{W}=$ spring wheat, $\mathrm{O}=\mathrm{oats}$, $\mathrm{G}=$ rye grass. ${ }^{*}$ significant difference between treatments $(\mathrm{P}=0.05)$.

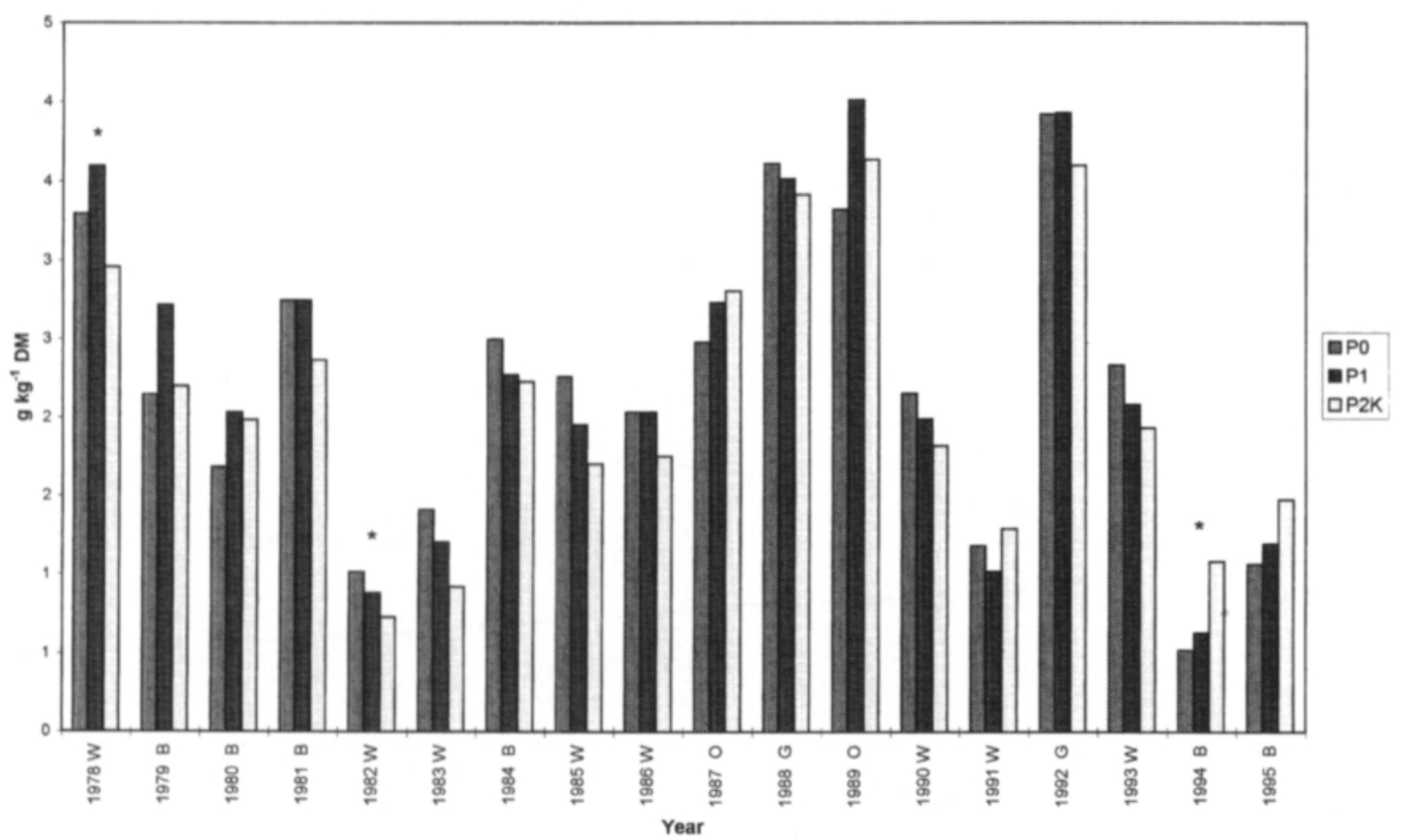

Fig. 4. P concentration in straw or grass. Letter after year denotes the following crops: $\mathrm{B}=\mathrm{barley}, \mathrm{W}=\mathrm{spring}$ wheat, $\mathrm{O}=\mathrm{oats}$, $\mathrm{G}=$ rye grass. * significant difference between treatments $(\mathrm{P}=0.05)$. 


\section{AGRICULTURAL AND FOOD SCIENCE IN FINLAND}

Jaakkola, A. et al. Effect of fertilization on soil phosphorus

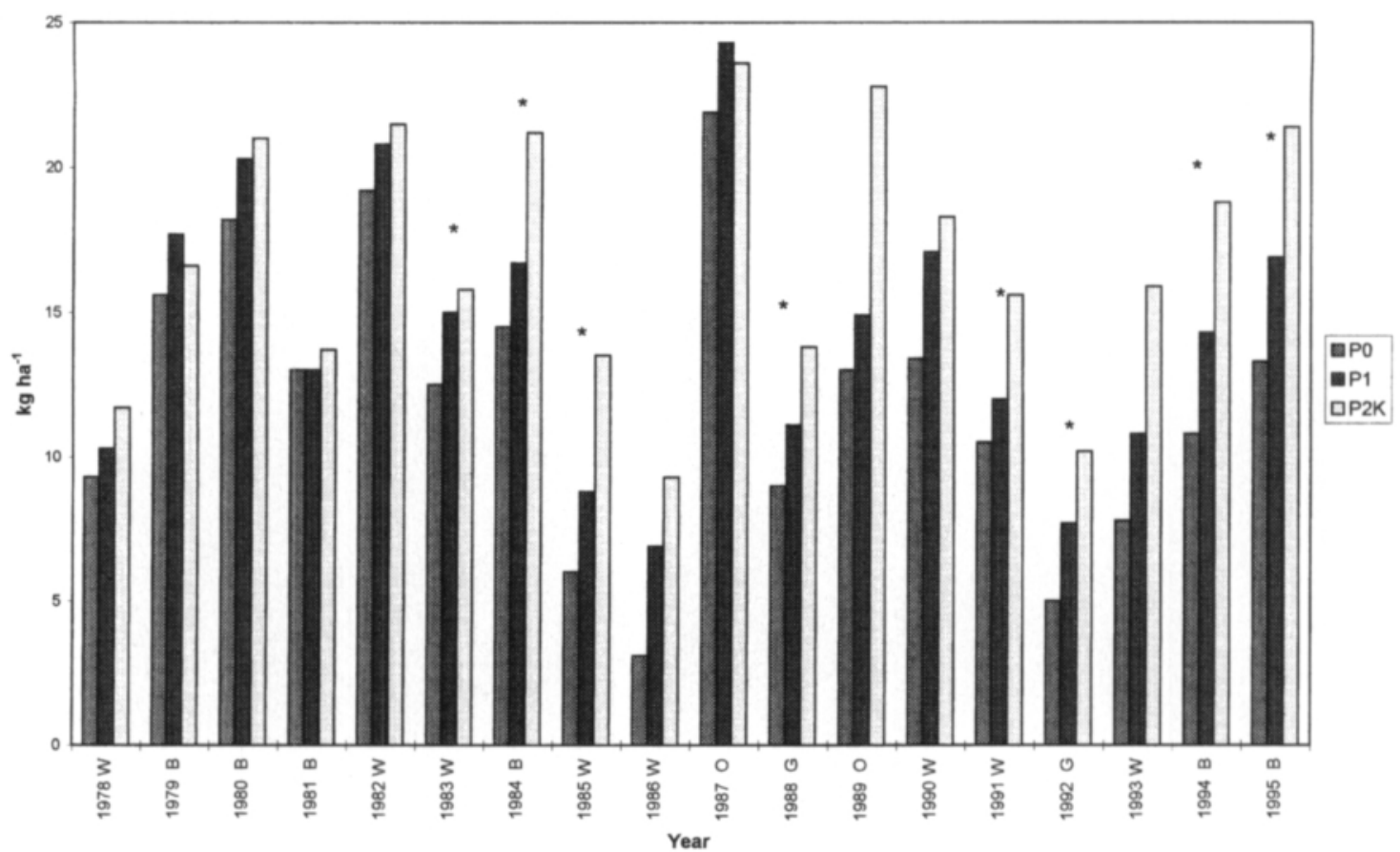

Fig. 5. $\mathrm{P}$ uptake by the crop. Letter after year denotes the following crops: $\mathrm{B}=$ barley, $\mathrm{W}=$ spring wheat, $\mathrm{O}=\mathrm{oats}, \mathrm{G}=$ rye grass. *significant difference between treatments $(\mathrm{P}=0.05)$.

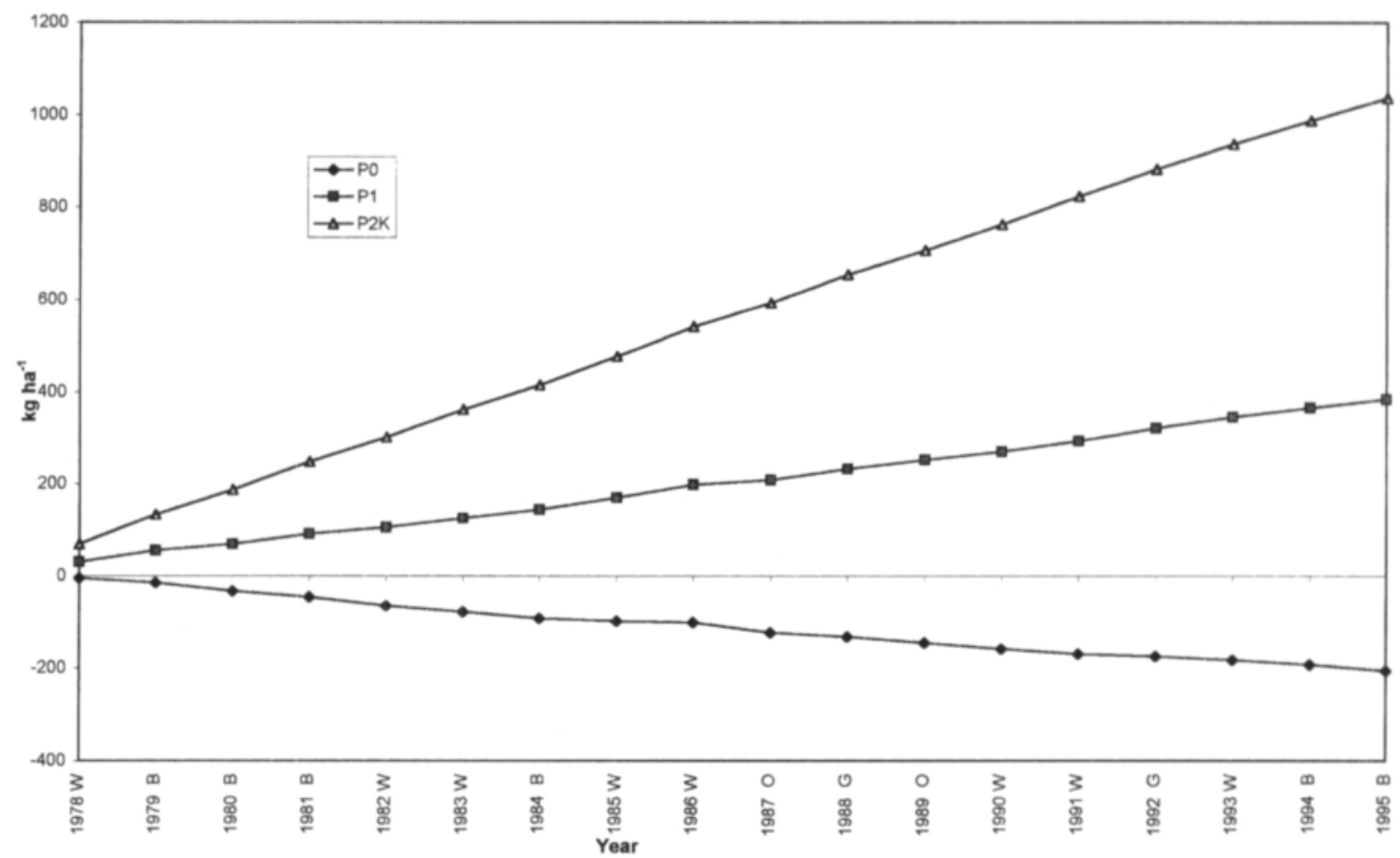

Fig. 6. Cumulative $P$ balance. Letter after year denotes the following crops: $B=$ barley, $W=$ spring wheat, $\mathrm{O}=$ oats, $\mathrm{G}=$ rye grass. *significant difference between treatments $(\mathrm{P}=0.05)$. 
Vol. 6 (1997): 313-322.

Table 2. $\mathrm{pH}$ and inorganic $\mathrm{P}$ extracted sequentially by the fractionation procedure as well as organic $\mathrm{P}$.

\begin{tabular}{llccccccc}
\hline Year & Treatment & $\mathrm{pH}$ & $\begin{array}{c}\mathrm{NH}_{4} \mathrm{Cl} \\
\mathrm{mg} \mathrm{kg}^{-1}\end{array}$ & $\begin{array}{c}\mathrm{NH}_{4} \mathrm{~F} \\
\mathrm{mg} \mathrm{kg}^{-1}\end{array}$ & $\begin{array}{c}\mathrm{NaOH} \\
\mathrm{mg} \mathrm{kg}^{-1}\end{array}$ & $\begin{array}{c}\mathrm{H}_{2} \mathrm{SO}_{4} \\
\mathrm{mg} \mathrm{kg}^{-1}\end{array}$ & $\begin{array}{c}\text { Organic P } \\
\mathrm{mg} \mathrm{kg}^{-1}\end{array}$ & $\begin{array}{c}\Sigma \\
\mathrm{mg} \mathrm{kg}^{-1}\end{array}$ \\
\hline 1978 & $\mathrm{P}_{0}$ & $7.1^{\mathrm{a}}$ & $9^{\mathrm{a}}$ & $246^{\mathrm{a}}$ & $155^{\mathrm{a}}$ & $195^{\mathrm{a}}$ & $244^{\mathrm{a}}$ & $849^{\mathrm{a}}$ \\
& $\mathrm{P}_{1}$ & $7.2^{\mathrm{a}}$ & $10^{\mathrm{a}}$ & $245^{\mathrm{a}}$ & $161^{\mathrm{a}}$ & $198^{\mathrm{a}}$ & $231^{\mathrm{a}}$ & $845^{\mathrm{a}}$ \\
& $\mathrm{P}_{2} \mathrm{~K}$ & $7.2^{\mathrm{a}}$ & $12^{\mathrm{a}}$ & $265^{\mathrm{a}}$ & $161^{\mathrm{a}}$ & $191^{\mathrm{a}}$ & $284^{\mathrm{a}}$ & $913^{\mathrm{b}}$ \\
1984 & $\mathrm{P}_{0}$ & $7.0^{\mathrm{a}}$ & $8^{\mathrm{a}}$ & $231^{\mathrm{a}}$ & $148^{\mathrm{a}}$ & $195^{\mathrm{a}}$ & $203^{\mathrm{a}}$ & $785^{\mathrm{a}}$ \\
& $\mathrm{P}_{1}$ & $7.1^{\mathrm{a}}$ & $8^{\mathrm{a}}$ & $259^{\mathrm{ab}}$ & $164^{\mathrm{ab}}$ & $208^{\mathrm{a}}$ & $209^{\mathrm{a}}$ & $848^{\mathrm{a}}$ \\
& $\mathrm{P}_{2} \mathrm{~K}$ & $7.0^{\mathrm{a}}$ & $10^{\mathrm{a}}$ & $301^{\mathrm{b}}$ & $176^{\mathrm{b}}$ & $189^{\mathrm{a}}$ & $245^{\mathrm{a}}$ & $921^{\mathrm{a}}$ \\
1990 & $\mathrm{P}_{0}$ & $7.1^{\mathrm{a}}$ & $3^{\mathrm{a}}$ & $210^{\mathrm{a}}$ & $145^{\mathrm{a}}$ & $201^{\mathrm{a}}$ & $198^{\mathrm{a}}$ & $757^{\mathrm{a}}$ \\
& $\mathrm{P}_{1}$ & $7.1^{\mathrm{a}}$ & $6^{\mathrm{ab}}$ & $260^{\mathrm{ab}}$ & $169^{\mathrm{b}}$ & $212^{\mathrm{a}}$ & $188^{\mathrm{a}}$ & $835^{\mathrm{a}}$ \\
& $\mathrm{P}_{2} \mathrm{~K}$ & $7.1^{\mathrm{a}}$ & $10^{\mathrm{b}}$ & $343^{\mathrm{b}}$ & $195^{\mathrm{b}}$ & $206^{\mathrm{a}}$ & $227^{\mathrm{a}}$ & $981^{\mathrm{b}}$ \\
& $\mathrm{P}_{0}$ & $7.1^{\mathrm{a}}$ & $3^{\mathrm{a}}$ & $203^{\mathrm{a}}$ & $158^{\mathrm{a}}$ & $193^{\mathrm{a}}$ & $193^{\mathrm{a}}$ & $750^{\mathrm{a}}$ \\
& $\mathrm{P}_{1}$ & $6.9^{\mathrm{a}}$ & $5^{\mathrm{ab}}$ & $247^{\mathrm{a}}$ & $182^{\mathrm{a}}$ & $200^{\mathrm{a}}$ & $196^{\mathrm{a}}$ & $830^{\mathrm{a}}$ \\
& $\mathrm{P}_{2} \mathrm{~K}$ & $7.0^{\mathrm{a}}$ & $9^{\mathrm{b}}$ & $356^{\mathrm{b}}$ & $215^{\mathrm{b}}$ & $198^{\mathrm{a}}$ & $207^{\mathrm{a}}$ & $985^{\mathrm{b}}$ \\
\hline
\end{tabular}

Means of the same year and the same column followed by a common letter do not differ significantly (Tukey, $\mathrm{P}=0.05$ ),

increased the $\mathrm{NH}_{4} \mathrm{Cl}$ extractable $\mathrm{P}$ significantly in 1990 and 1995, but some tendency could be seen earlier. In the $\mathrm{P}_{0}$ treatment this fraction decreased with time. However, a similar tendency was obvious even in $\mathrm{P}_{2} \mathrm{~K}$. All the samples were dominated by the $\mathrm{NH}_{4} \mathrm{~F}-\mathrm{P}$ in which significant differences between the treatments were detected since 1984. As compared to the beginning of the experiment, $\mathrm{NH}_{4} \mathrm{~F}-\mathrm{P}$ showed a slight decrease when no $\mathrm{P}$ was given, an increase at the $\mathrm{P}$ fertilization level 70-79 $\mathrm{kg} \mathrm{ha}^{-1} \mathrm{a}^{-1}$, and no clear change at $35 \mathrm{~kg} \mathrm{P}^{-1} \mathrm{a}^{-1}$. Similar differences between the treatments were observed in $\mathrm{NaOH}-\mathrm{P}$. However, in contrast to $\mathrm{NH}_{4} \mathrm{~F}-\mathrm{P}$, this fraction was not depleted by the continuous cultivation without $\mathrm{P}$ fertilization. The $\mathrm{H}_{2} \mathrm{SO}_{4}$ soluble fraction did not respond to the treatments. The or- ganic phosphorus tended to decrease during the experimental period but there were no significant differences between fertilization treatments. The sum of the fractions responded to the treatments rather logically. However, the difference between $\mathrm{P}_{0}$ and $\mathrm{P}_{1}$ was not statistically significant.

Phosphorus extractable with acid ammonium acetate $\left(\mathrm{P}_{\text {aac }}\right)$ decreased with time in the soil not amended with $\mathrm{P}$ (Table 3 ). No changes were found at the lower $\mathrm{P}$ fertilization level although the $\mathrm{P}$ balance was positive. In the $\mathrm{P}_{2} \mathrm{~K}$ treatment, $\mathrm{P}_{\text {aac }}$ showed an increasing trend. The differences between treatments became significant in 1990.

At the beginning of the experiment, the concentration of the water extractable $\mathrm{P}\left(\mathrm{P}_{\mathrm{w}}\right)$ was about half of the acid ammonium acetate extract-

Table 3. Phosphorus extractable with acid ammonium acetate, $\mathrm{P}_{\text {aac }}\left(\mathrm{mg} \mathrm{kg}^{-1}\right)$ and water $\mathrm{P}_{\mathrm{w}}\left(\mathrm{mg} \mathrm{kg}^{-1}\right)$.

\begin{tabular}{|c|c|c|c|c|c|c|c|c|}
\hline \multirow[t]{2}{*}{ Treatment } & \multicolumn{2}{|c|}{1978} & \multicolumn{2}{|c|}{1984} & \multicolumn{2}{|c|}{1990} & \multicolumn{2}{|c|}{1995} \\
\hline & $P_{\text {ax }}$ & $\mathrm{P}_{\mathrm{w}}$ & $\mathrm{P}_{\operatorname{axc}}$ & $\mathrm{P}_{w}$ & $\mathrm{P}_{\operatorname{axc}}$ & $\mathrm{P}_{w}$ & $\mathrm{P}_{\operatorname{ax}}$ & $\mathrm{P}_{\mathrm{w}}$ \\
\hline $\mathbf{P}_{0}$ & $31^{a}$ & $14^{k}$ & $25^{\mathrm{a}}$ & $12^{k}$ & $19^{a}$ & $9^{k}$ & $20^{a}$ & $6^{k}$ \\
\hline$P_{1}$ & $33^{a}$ & $14^{k}$ & $32^{a}$ & $16^{k}$ & $31^{b}$ & $17^{1}$ & $34^{a b}$ & $17^{\prime}$ \\
\hline $\mathrm{P}_{2} \mathrm{~K}$ & $35^{a}$ & $14^{k}$ & $37^{a}$ & $17^{k}$ & $43^{c}$ & $22^{\prime}$ & $50^{b}$ & $26^{\mathrm{m}}$ \\
\hline
\end{tabular}

Each extract is tested separately. Means in the same column followed by a common letter do not differ significantly (Tukey, $\mathrm{P}=0.05$ ). 
able P (Table 3). In the plots cultivated without $P$ fertilization it decreased very clearly with time being at the end of the experiment only one third of $\mathrm{P}_{\text {aac }}$. In treatment $\mathrm{P}_{2} \mathrm{~K}$, on the contrary, $\mathrm{P}_{\mathrm{w}}$ almost doubled until 1995. A small increase might have taken place also in treatment $\mathrm{P}_{1}$. The difference between treatments became significant from 1990 on but was obvious already in 1984 .

\section{Discussion}

No significant trend of increasing yield differences between treatments over time could be observed although the unfertilized plots were exhausted and the fertilized ones were enriched with P. At the higher P fertilization level, the yield increase is, no doubt, attributable to $\mathrm{K}$ applied with the fertilizer. The $\mathrm{P}$ application affected the $\mathrm{P}$ concentration in the crops very little as compared with the variation between years due to plant species, harvesting time and weather during the growing season. In general concentrations were at the range reported by Jaakkola et al. (1982). The conclusion can be made that the fertilization-induced increase in the $\mathrm{P}$ uptake was mainly caused by an increase in crop yield.

According to Saarela et al. (1995) a yield increase of cereals or hay seldom takes place due to $\mathrm{P}$ application in a soil with over $30 \mathrm{mg} \mathrm{l}^{-1} \mathrm{P}_{\text {aac }}$. Not even the $20 \mathrm{mg} \mathrm{l}^{-1}$ to which the $\mathrm{P}_{\text {aac }}$ concentration dropped in the non-fertilized soil would usually be low enough to facilitate a yield response. Therefore, the positive yield response to the $\mathrm{P}$ application probably obtained in the present study is surprising. One reason for the unexpected behavior might be that in the present study the soil pH was much higher (6.7-7.3) than normally found in Finnish soils. The extraction power of acid acetate is highly dependent on soil $\mathrm{pH}$ (Griffin 1971, Hartikainen 1989a). In fact, the acid-acetate test is shown to overestimate plantavailable P reserves in limed soils (Hartikainen 1989a).
On the other hand, the experimental soil was initially very rich in $\mathrm{P}_{w}$ as compared to the values reported in some previous studies (Hartikainen 1982, Sippola and Saarela 1986). $P_{w}$ amounted only to 30 to 55 per cent of $P_{\text {aac }}$ but responded during the experimental period relatively more sensitively to the $\mathrm{P}$ fertilization regimes.

Also the $\mathrm{NH}_{4} \mathrm{Cl}-\mathrm{P}$ obtained by the Chang and Jackson fractionation was initially rather high. Its range in Finnish soils is usually $1-4 \mathrm{mg} / \mathrm{kg}$, and values above $10 \mathrm{mg} / \mathrm{kg}$ can be found only occasionally (see Kaila 1965b, Hartikainen 1979). Actually, this fraction comprises a part of $\mathrm{P}_{\mathrm{w}}$ and reflects the $\mathrm{P}$ saturation degree on the surfaces of Al- and Fe-oxides (Hartikainen 1982). In Finnish soils, the fertilizer $P$ has been shown to accumulate on these compounds (Kaila 1965a, Hartikainen 1989b, Yli-Halla 1989). The dominance of the $\mathrm{NH}_{4} \mathrm{~F}-\mathrm{P}$ assumed to represent Al-bound $\mathrm{P}$ over the $\mathrm{NaOH}-\mathrm{P}$ supposed to be bound by $\mathrm{Fe}$ agreed with the relative higher abundance of the $\mathrm{Al}$ oxides. Accordingly, the bulk of the accumulated fertilizer $\mathrm{P}$ was recovered in the Al-bound fraction. The high soil $\mathrm{pH}$ favouring the $\mathrm{P}$ retention by $\mathrm{Al}$ oxides at the expense of Fe oxides (Kaila 1965c, Hartikainen 1981, 1983) might contribute this reaction pattern. As in previous studies (Kaila 1965a, Hartikainen 1989 b) the $\mathrm{H}_{2} \mathrm{SO}_{4}-\mathrm{P}$ representing Cabound fraction was found to be inactive in $\mathrm{P}$ retention.

The depletion in the $\mathrm{NH}_{4} \mathrm{~F}-\mathrm{P}$ in the plots cultivated without $\mathrm{P}$ fertilization being higher than that in the $\mathrm{NaOH}-\mathrm{P}$ can be taken to indicate that the Al-bound $\mathrm{P}$ was more labile than $\mathrm{Fe}$-bound $\mathrm{P}$ and, thus, more important as a $\mathrm{P}$ source for the crop. The $\mathrm{H}_{2} \mathrm{SO}_{4}-\mathrm{P}(\mathrm{Ca}-\mathrm{P})$, in turn, showed to be of low availability. This is in agreement with the observation made in an earlier 7-year field experiment with 16 acid soils: this fraction was not affected in 10 soils and reduced in 6 soils (Hartikainen 1989b).

According to regression analysis the mean decrease of the sum of fractions in the $\mathrm{P}_{0}$ treatment was $5.8 \mathrm{mg} \mathrm{kg}^{-1}$ per year. Assuming a ploughing depth of $23 \mathrm{~cm}$ and dry bulk density of $1.14 \mathrm{~kg} \mathrm{l}^{-1}$ the annual decrease of $\mathrm{P}$ reserves 


\section{AGRICULTURAL AND FOOD SCIENCE IN FINLAND}

Vol. 6 (1997): 313-322.

was $15 \mathrm{~kg} \mathrm{ha}^{-1}$. It was greater than the mean annual $\mathrm{P}$ balance of $-11 \mathrm{~kg} \mathrm{ha}^{-1}$. In the $\mathrm{P}_{1}$ and $\mathrm{P}_{2} \mathrm{~K}$ treatments the mean annual changes of the sum of fractions were -1.0 and $4.9 \mathrm{mg} \mathrm{kg}^{-1}$ corresponding to -3 and $13 \mathrm{~kg} \mathrm{ha}^{-1}$, respectively. These figures do not agree with the mean annual balances which were 21 and $58 \mathrm{~kg} \mathrm{ha}^{-1}$.

In long-term field experiments the movement of soil and fertilizers from a plot to a neighbouring plot and vice versa is a well-known problem discussed in detail by Sibbesen (1986). The plots with treatments $\mathrm{P}_{1}$ and $\mathrm{P}_{2} \mathrm{~K}$ were only $5 \mathrm{~m}$ wide while the $\mathrm{P}_{0}$ and $\mathrm{P}_{1} \mathrm{~K}$ treated plots being neighbours to $P_{1}$ and $P_{2} K$, respectively, were $20 \mathrm{~m}$ wide. The length of all the plots was $15 \mathrm{~m}$. A net plot of 4 by $11 \mathrm{~m}$ was usually harvested lengthwise in the middle of each plot from south west to north east.

Calculations according to the model of Sibbesen (1986) revealed that during this 18-year experiment the exchange of soil between plots may have increased the $\mathrm{P}$ content in the treatment $\mathrm{P}_{0}$ at a rate of $30 \mathrm{~kg} \mathrm{ha}^{-1}$ (for transport co- efficient $\left.\mathrm{D}=0.4 \mathrm{~m}^{2} \mathrm{a}^{-1}\right)$. So, the corrected annual $\mathrm{P}$ balance in the $\mathrm{P}_{0}$ treatment should have been about $-9 \mathrm{~kg} \mathrm{ha}^{-1}$. Considering the large random variation of the analytical results as well as the inaccuracies in determining the ploughing depth and bulk density the agreement with the change in soil $\mathrm{P}$ reserves $\left(-15 \mathrm{~kg} \mathrm{ha}^{-1} \mathrm{a}^{-1}\right)$ is satisfactory.

In the $\mathrm{P}$ amended net plots the decrease due to soil movement would be about $14 \mathrm{~kg} \mathrm{ha}^{-1} \mathrm{a}^{-1}$. The decrease is similar for $\mathrm{P}_{1}$ and $\mathrm{P}_{2} \mathrm{~K}$ because the difference in $\mathrm{P}$ application rate between neighbouring plots is equal. The corrected annual $\mathrm{P}$ balances should be 7 and $44 \mathrm{~kg} \mathrm{ha}^{-1}$ as compared with changes in soil $\mathrm{P}$ reserves of -3 and $13 \mathrm{~kg}$ ha $^{-1} \mathrm{a}^{-1}$ for $\mathrm{P}_{1}$ and $\mathrm{P}_{2} \mathrm{~K}$, respectively. So, the agreement is not very good. It is obvious that the soil movement has been more vigorous than the value of the transport coefficient $\left(\mathrm{D}=0.4 \mathrm{~m}^{2} \mathrm{a}^{-1}\right.$ ) adopted from Sibbesen (1986) presupposes. Some P may also have moved to the deeper layers. In addition, on this sloping field $1-2 \mathrm{~kg} \mathrm{ha}^{-1}$ of phosphorus might have been lost by leaching and surface runoff (Rekolainen 1989).

\section{References}

Barrow, N.J. 1974. Effect of previous additions of phosphate on phosphate adsorption by soils. Soil Science 118: 82-89.

Campbell, R.E. 1965. Phosphorus fertilizer residual effects on irrigated crops in rotation. Soil Science Society of America Proceedings 29: 67-70.

Elonen, P. 1971. Particle-size analysis of soil. Acta Agralia Fennica 122: 1-122.

Graham, E.R. 1948. Determination of soil organic matter by means of a photoelectric colorimeter. Soil Science 65: 181-183.

Griffin, G.F. 1971. Effect of liming on the soil test level of phosphorus as determined by three methods. Soil Science Society of America Proceedings 35: 540-42.

Halvorsson, A.D. \& Black, A.L. 1985. Fertilizer phosphorus recovery after seventeen years of dryland cropping. Soil Science Society of America Journal 49: 933-937.

Hartikainen, H. 1979. Phosphorus and its reactions in terrestrial soils and lake sediments. Journal of the Scientific Agricultural Society of Finland 51: 537-624.

- 1981. Effect of decreasing acidity on the extractability of inorganic soil phosphorus. Journal of the Scientific Agricultural Society of Finland 53: 16-26.

- 1982. Water soluble phosphorus in Finnish mineral soils and its dependence on soil properties. Journal of the Scientific Agricultural Society of Finland 54: 89-98.

- 1983. Effect of liming on phosphorus in two soils of different organic matter content. 1. Changes of native and applied phosphorus in incubation experiment. Journal of the Scientific Agricultural Society of Finland 55: 345-354.

- 1989a. Evaluation of water and ammonium acetate tests as indices for available $\mathrm{P}$ in limed soil. Journal of Agricultural Science in Finland 61: 1-6.

- 1989b. Effect of cumulative fertilizer dressings on the phosphorus status of mineral soils. 1. Changes on inorganic phosphorus fractions. Journal of Agricultural Science in Finland 61: 55-59.

- 1991. Potential mobility of accumulated phosphorus in soil as estimated by the indices of $Q / 1$ plots and by extractant. Soil Science 152: 204-209.

Jaakkola, A., Syvălahti, J. \& Saari, E. 1982. Contents of mineral elements in Finnish cereal straw. Journal of the Scientific Agricultural Society of Finland 54: 385394.

Kaila, A. 1963. Dependence of soil sorption capacity on the aluminium and iron in Finnish soils. Journal of the Scientific Agricultural Society of Finland 35: 165177. 


\title{
AGRICULTURAL AND FOOD SCIENCE IN FINLAND
}

Jaakkola, A. et al. Effect of fertilization on soil phosphorus

- 1965a. The fate of water-soluble phosphate added to some mineral soils. Journal of the Scientific Agricultural Society of Finland 37: 104-115.

- 1965b. Some phosphorus test values and fractions of inorganic phosphorus in soils. Journal of the Scientific Agricultural Society of Finland 37: 175-185.

- 1965c. Effect of liming on the mobilization of soil phosphorus. Journal of the Scientific Agricultural Society of Finland 37: 243-254.

Niskanen, R. 1989. Extractable aluminium, iron and manganese in mineral soils. 2. Extractability by oxalate and pyrophosphate. Journal of Agricultural Science in Finland 61: 79-87.

Rekolainen, S. 1989. Phosphorus and nitrogen load from forest and agricultural areas in Finland. Aqua Fennica 19: 92-107.

Saarela, I., Järvi, A., Hakkola, H. \& Rinne, K. 1995. Fosforilannoituksen porraskokeet 1977-1994. Vuosittain annetun fosforimăărăn vaikutus maan viljavuuteen ja peltokasvien satoon monivuotisessa kenttäkokeessa. Maatalouden tutkimuskeskus, Tiedote 16/95. 94 p.
Sibbesen, E. 1986. Soil movement in long term field experiments. Plant and Soil 91: 73-85.

Sippola, J. \& Saarela, I. 1986. Some extraction methods as indicators of need for phosphorus fertilization. Annales Agriculturae Fennica 25: 265-271.

Tamm, O. 1922. Eine Methode zur Bestimmung der anorganischen Komponente des Gelkomplexes im Boden. Statens Skogsförsöksanstalt, Meddelande 19: 387404.

Vuorinen, J. \& Măkitie, O. 1955. The method of soil testing in use in Finland. Agrogeological Publication 63: $1-44$.

Yli-Halla, M. 1989. Effect of different rates of P fertilization on the yield and $\mathrm{P}$ status of the soil in two longterm field experiments. Journal of Agricultural Science in Finland 61: 361-370.

- , Hartikainen, H., Ekholm, P., Turtola, E. \& Kallio, K. 1995. Assessment of soluble phosphorus load in surface runoff by soil analyses. Agriculture, Ecosystem \& Environment 56: 53-62.

\section{SELOSTUS}

\section{Maan fosforitilan muutos pitkäaikaisessa kenttäkokeessa hietamaalla}

\author{
Antti Jaakkola, Helinä Hartikainen ja Riitta Lemola \\ Helsingin yliopisto
}

Vuonna 1978 Etelä-Suomeen hietamaalle perustetun kenttäkokeen tarkoitus oli seurata erilaisten vuosittaisten fosforilannoituskäsittelyjen vaikutusta maan fosforitilaan. Koekentällä kasvoi viljakasveja tai raiheinää 18 vuoden ajan. Koejakson aikana yhtä koejäsentä ei lannoitettu lainkaan fosforilla ja muille koejäsenille annettiin $35 \mathrm{~kg} \mathrm{ha}^{-1}$ tai $70-79 \mathrm{~kg} \mathrm{ha}^{-1}$ vuotuinen fosforilannoitus. Fosforilla lannoitetuissa koejäsenissä jyväsato oli keskimäärin suurempi kuin ilman fosforilannoitusta viljellyssä koejäsenessä. Alemmalla fosforilannoitustasolla ero ei kuitenkaan ollut tilastollisesti merkitsevä. Ylemmällä tasolla yht'aikaa annettu kaliumlannoitus aiheutti sen, ettei tilastollisesti merkitsevää eroa voitu kiistatta lukea fosforilannoituksen ansioksi. Ilman fosforia viljelty koejäsen köyhtyi fosforin suhteen ja fosforilla lannoitettuihin koejäseniin kertyi fosforia.

Maan epäorgaanisia fosforireservejä luokittelevan Changin ja Jacksonin fraktiointianalyysin perusteella maahan kertynyt fosfori näytti pidättyvän pääasiassa alumiinioksideihin ja vähäisemmässä määrin rautaoksideihin. Alumiinin sitoma fosfori osoittautui myös kasvien pääasialliseksi fosforilähteeksi ilman fosforilannoitusta viljellyssä koejäsenessä. Lannoituskäsittelyt eivät vaikuttaneet kalsiumin sitomaan fosforiin. Maan kyntökerroksen epäorgaanisissa ja orgaanisissa fosforivaroissa tapahtunut muutos ei täysin vastannut fosforitasetta, joka laskettiin maahan lisätyn fosforin ja kasvin fosforinoton erotuksena, vaikka maa-aineksen todennäköinen kulkeutuminen vierekkäisten koeruutujen välillä otettiin laskennallisesti huomioon.

Kokeen aikana annetun lannoituksen vaikutusta fosforireservien käyttökelpoisuuteen arvioitiin vesiuuton ja Suomessa viljavuusanalyysissä käytettävän happaman ammoniumasetaattiuuton avulla. Kummallakin menetelmällä mitattu kasveille käyttökelpoisen fosforin määrä väheni ilman fosforia viljellyssä koejäsenessä asteittain kokeen edetessä ja kasvoi fosforilannoituksen saaneissa koejäsenissä maahan kertyneen fosforin määrän lisääntyessä. Vesi uutti 30$55 \%$ happamaan ammoniumasetaattiin uuttuvan fosforin määrästä. Vesiuuttoinen fosfori kuvasi erilaisen lannoituksen aiheuttamaa muutosta maan fosforivaroissa vähän paremmin kuin happamaan ammoniumasetaattiin uuttuva fosfori. 